\title{
Transmission Mechanism of Exchange Rate Pass-Through to Domestic Price: The Case of Afghanistan
}

\author{
Ajmal $\operatorname{Arian}^{1} \&$ Arabi U. ${ }^{2}$ \\ ${ }^{1}$ Faculty of Economics, Kabul University, Afghanistan \\ ${ }^{2}$ Department of Economics, Mangalore University, Mangalagangothri, Karnataka, India \\ Correspondence: Ajmal Arian, Faculty of Economics, Kabul University and Research Scholar in Department of \\ Economic at Mangalore University, Mangalagangothri - 574 199, Karnataka, India. E-mail: \\ ajmalarian1@gmail.com
}

Received: December 7, 2019

Accepted: December 19, 2019

Online Published: March 30, 2020

doi:10.5539/ass.v16n4p1

URL: https://doi.org/10.5539/ass.v16n4p1

\begin{abstract}
This article investigates the mechanism of exchange rate pass-through to the prices in the context of the Islamic Republic of Afghanistan's economy. This study explored the magnitude and speed of the pass-through effect on the prices by analyzing quarterly data from 2003 Q1 to 2019 Q2 considering five variables (viz., world food price index, foreign reserves, money supply, import price, and nominal effective exchange rate) based on the Vector Autoregression Model (VAR) with the cointegration and innovation accounting tools such has impulse response function and variance decomposition. The findings of the study suggest that the exchange rate pass-through in Afghanistan is incomplete. The import price is highly responsive in the short-run and moderately responsive an increasingly smooth movement in the long-run. However, CPI in the short-run with swift positive respond but the long-run smooth increasing movement. Furthermore, variance decomposition evidence shows that import price is affected by FR, NEER, CPI, and MS in both short-run and long-run, but the CPI strongly lagged by its variance, WFP, NEER, import price, and MS.
\end{abstract}

Keywords: Cointegration, Exchange Rate Pass-Through, IRF, Price, VAR, VD

\section{Introduction}

The Afghanistan's national currency (Afghani) has been continuously experiencing gradual depreciation against foreign currencies, particularly USD. In spite of the fact that the monetary system, particularly currency, was the benchmark of all economic reforms and restructuring of the economic system in the new era (Official Gazette, 808, 2003). At the end, it is awash in money. Since the Central Bank of Afghanistan (Da Afghanistan Bank) could not meet the conventional objectives of a decent monetary system, Afghani does not manoeuvre as a reliable means of payment and a useful store of value. Likewise, high dependency on foreign aid and a chronic deficit of the balance of trade made the economy extremely susceptible to exchange rate volatility. If the monetary authorities not countered by the right policy, the continuum of such economic situations brings down the economy to the knee.

The results of currency depreciation alongside other macroeconomic variables turned to domestic price first of all. Many monetary and balance of payment models assumed one to one relationship between the exchange rate and domestic prices, but the findings of empirical studies have rejected the assumption unanimously, particularly in the short run. The adjustment of domestic prices against exchange rate variation influences by lags. The existence of the significant lags, in the transmission process of the exchange rate to domestic price, the effects of pass-through would be small.

The degree of exchange rate pass-through has essential implications for the formulation of policy to contract inflation as well as trade implication of an exchange rate shock. However, the exchange rate pass through effects and dynamics have not been still explained and quantified.

This study is designed to investigate the exchange rate pass-through in the context of the Afghan economy. We will use a theoretical and econometric framework. This study is decomposed into the literature review, an overview of the Afghan context, modeling, estimation of pass-through effects, empirical findings, suggestion, and the conclusion of the study. 


\section{Theoretical Background and Literature Review}

This literature survey is a brief review of the theoretical and empirical background. The theoretical background is confined to some theoretical underpinning and determinants, and empirical section consists of some empirical evidence.

\subsection{Theoretical Background}

The adjustment role of arbitrage transmitted the differences in inflation rates in concerning two countries through the relative exchange rate in the long run "PPP postulate." It means that the exchange rate pass-through theoretical depends on the doctrine of purchasing power parity. The channel in which the exchange rate fluctuation affects the domestic price is called the exchange rate pass-through (hereinafter) ERPT. "The impact of nominal depreciation on the inflation rate is called pass-through from exchange to inflation"(Terra, 2015).

(Menon, 1994) defined "ERTP is the degree to which exchange rate changes are reflected in the destination currency prices of traded goods. " i.e., the percentage change in nominal prices follows a one percent change in the exchange rate between the exporting and importing country.

The exchange rate is a key parameter in policy development and macro-economic management. Thereby the exchange rate issue has significant implication in external adjustment (Krugman \& Obstfeld, 2003); transmission to inflation (Krugman, 1986; Smets \& Wouters, 2002; Gagnon \& Ihrig, 2001); international transmission of shocks, the choice of the exchange rate regime (Engel, 2000; Devereux \& Engel, 2002) and adoption of monetary policy.

Adjustment speed due to the exchange rate movements depend on some determinants which are the outcome of plenty of investigations, which classified in two parts micro and macro determinants (Campa \& Goldberg, 2002). In a nutshell, some of the micro determinants are: pricing to market strategy of the firm (PTM) (Krugman, 1986; Gaulier, 2006) firm or industry's market structure (Dornbusch, 1985; Menon, 1995; Yang, 1997), market share (Knetter, 1993), product differentiation (Dornbusch, 1985; Goldberg \& Kenetter, 1997), and substitution effect (Burstein, Eichenbaum, \& Rebelo, 2002). As well as the macro determinants included from the size of the economy, inflationary environment, exchange rate regime, central bank autonomy, monetary policy framework and credibility, consumption basket, the output gap, business cycle, trade openness, global value chains integration degree and foreign currency invoicing (Frankel, Parsley, \& Wei, 2005; Taylor, 2000; Choudhri \& Hakura, 2006; Schmidt-Hebbel \& Tapia, 2002; Menon, 1995; Devereux \& Engel, 2002; Schmidt-Hebbel \& Tapia, 2002; Carrière-Swallow et al., 2016; Khundrakpam, 2007; Bogdanski, Tombini, \& Werlang, 2000; Bogdanski et al., 2000; Auer, 2015; Berman, Martin, \& Mayer, 2014; Mccarthy, 2000; Georgios, Gr“ab, \& Khalil, 2017; Reinhart, Rogof, \& Savastano, 2014).

All the determinants mentioned above explain and quantify the magnitude, speed, completeness, incompleteness, symmetry, and asymmetry of ERPT.

Completeness and incompleteness of ERPT depend on the movement of the exchange rate. If any changes in foreign exchange rate is reflected in domestic prices in such ways to depict one to one relationships it is called complete pass through, or else it is incomplete pass-through (Goldberg \& Kenetter, 1997). Furthermore, exchange rate movements influence the economy in two ways direct and indirect change. Direct changes refer to the changes in consumer prices against the exchange rate fluctuation and vice versa the indirect, refers to changes in the composition of demand and wages (Laflèche, 1996).

\subsection{Empirical Background}

Empirically the theory of ERPT is tested in different methods and contexts to verify the validity of the theoretical propositions. These studies are roughly categorized in the micro and macro domains. The historical origin of the ERPT studies goes back to the micro-domain, but after the 1990s, clear cut change in economies raises the question about the macro aspects. The main question to be answered is that, despite large depreciation of national currency, inflation is low, it was the result of low global inflation environment, exchange rate volatility, import penetration, openness, import composition, trade distortions, transport costs and income have also been identified as essential determinants of pass-through (Taylor, 2000; Choudhri \& Hakura, 2001; Gagnan \& Ihrig, 2004; Goldfajn, 2000; Frankel et al., 2005).

A large number of empirical studies of pass-through effects on price are in the context of developed countries, but recently this phenomenon has been investigated by numerous authors in developing and small economies. The succinctness reviews of empirical literature in the country level and cross-countries are below.

(Menon, 1995) a critical study of ERPT literature. He discovered the features of the past studies in the context of 
country/s, data, methodology, and result of the study. The research mainly focused on industrialized countries, particularly the US economy.

(Webber, 1999) investigates ERPT in the realm of nine Asia-Pacific countries, discovered long-run co-integration in seven out of nine, partial ERPT for six out of seven. This study applied Johansen co-integration. Import prices response in the long-run extremely varied, which ranged (109\%) for Pakistan to (26\%) for Australia but in the short-run reflect, the ERPT was relatively slow.

(Mccarthy, 2000) by applying the VAR model to analyze the data from $(1976$ - 1998) for major industrialized countries, found out a moderate effect of pass-through on domestic prices showing a positive relation among import share, the degree of openness and ERPT, but negatively correlated to the foreign exchange rate volatility.

(Rowland, 2003) study of ERPT in the context of the Columbian economy estimated EPRT employing Vector Error Correction Model (VECM). The study shows incomplete ERPT to import and consumer prices. The calculated degrees of ERPT, respectively (80\%) to import prices, (28\%) producer prices, and consumer prices, and less than (15\%) reported per annum. However, he concluded the small ERPT on the consumer price.

(Campa \& Goldberg, 2005) Conducted a cross country investigation on 23 OECD countries data from (1975 2003 quarterly) using OLS estimation of log-transformed variables. This investigation reported (46\%) pass-through effects in local currency in the short-run and (64\%) in the long-run. The study concluded partial ERPT in the short-run and near to one in the long-run in OECD countries. Inflation rate and exchange rate variability are pointed out as the positive correlated macro-economic factors.

(Ito \& Sato, 2006) study of ERPT in crisis-hit economies finds out the various consequences of currency depreciation. SVAR applied, the findings indicate a high degree of ERPT to import price, but low to CPI except for Indonesia. The magnitude of pass-through of the exchange rate changes was larger on import prices of the countries that were more affected by the Asian crises.

(An, 2006) Assessed the exchange rate pass-through effect with cross-country data from eight industrialized economies, employing the VAR model. The study finds out incomplete pass-through at a different horizon. On the other hand, complete pass-through is evident sometimes. Meanwhile the study pointed out the declining of ERPT along the distribution chain.

(Sanusi, 2010) developed an SVAR model incorporated in the feature of the Ghanaian economy, particularly its dependence on foreign aid and the exports of primary goods to gain foreign currency. Evidence from the analysis, covering the period 1983Q3 through to 2006Q3, reveals that exchange rate pass-through to consumer prices in Ghana is substantial but incomplete. This study concluded that exchange rate depreciation is a potentially significant source of inflation in Ghana. The variance decomposition analyses found that monetary expansion has been more notable in explaining Ghana's actual inflationary process than the exchange rate depreciation. Finally, this study suggested policies that aim to mitigate the inflation must emphasis on monetary and exchange rate stability.

(Bhattacharya, Patnaik, \& Shah, 2011) explored weak pass-through. They used VECM to capture long-run and short-run relationships with the plugin of six variables: output, oil price, import price, domestic price, exchange rate, and short-term nominal interest rate. The study concluded that low ERPT depends on the low inflationary environment, pricing-to market behaviour by producers in the exporting countries, or the high share of non-traded goods in the country's domestic price index may result in a low exchange rate pass-through.

(Ozkan \& Erden, 2015) Conducted a comprehensive study using the combining of Dynamic Conditional Correlation and Generalized Autoregressive Conditional Heteroskedasticity (DCC-GARCH) and panel threshold regression analyses to assess time-varying exchange rate pass-through and macroeconomic determinants of the degree. This study covered a sample of (88) countries composed of 19 less-developed 41 developing and 28 advanced countries and found low ERPT over the past 30 years, especially dramatic declining since the mid of the 1990s. Further, the study evident a positive relationship between ERPT and average inflation but the negative response of inflation rate volatility to exchange rate volatility, the degree of openness, and the output gap.

(Helmy, Fayed, \& Hussien, 2018) adopted (SVAR) model, Impulse response function and variance decomposition to evident pass-through effects in Egypt. The results of the investigation indicate a positive relationship over three months and partial pass-through to producer price and consumer price, but statistically significant.

\section{Stylized Facts on Exchange Rate}

To calibrate the exchange rate pass-through to the domestic price in Afghanistan, its essential to shedding light 
on the exchange rate policy, inflation trends and policy measures. Accordingly, the contents of this section are the review of the Afghan macroeconomic environment.

Afghanistan is a small, open, and a developing country. A turbulent history features the economy of this country. Apart from the long past, demonetization and restructuring in the monetary system in 2002 were selected benchmark for the redefinition of the economic system as a whole by 2004 .

Policymakers and Da Afghanistan Bank (DAB), as the central bank of Afghanistan to alleviate anarchy in the monetary system, and pitch the ground for a sound and the amenable market-oriented economy. DAB decided to circulate the new banknotes, which are driven by the cancellation of three zero from the old bills. Monetary authorities aimed to maintain the soundness and fostering of the system to attain economic goals, monetary strategy delineated in such ways that monetary policy anchored on monetary aggregate, and exchange rate policy with the managed floating exchange rate.

Despite all of these courses of reforms, still, the country cannot meet the reliance point at all, mainly the Afghan economy is awash in money. Almost all parts of the economy are scored by foreign aids, particularly the reliant of the monetary management system highly foreign aids, and the demand side of the economy leaned on imports.

The rehabilitation of Afghanistan accompanied by the expansion of the foreign sector, whereas the economy was without any inward and outward-looking policy. The acute deficit of trade balance remained as a perpetual problem even if, the notable expansion in GDP and structure changes. The average difference between exports and imports from (2003-2018) is about (90\%). On the other hand, in recent years, the shrinking of foreign aids impacted the exchange rate considerably. All of such a tragic situation depressed the economy at different channels. Loads of all such depression are bearing by consumers, producers, and policy-making authorities, whereas making the economy more susceptible. One of the most significant affected phenomena is the exchange rate. The national currency has depreciated gradually, which speeds up in the recent seven years, even with the DAB serious intervention in the market through the auction of foreign currency as depicted in figure (Figure 1).

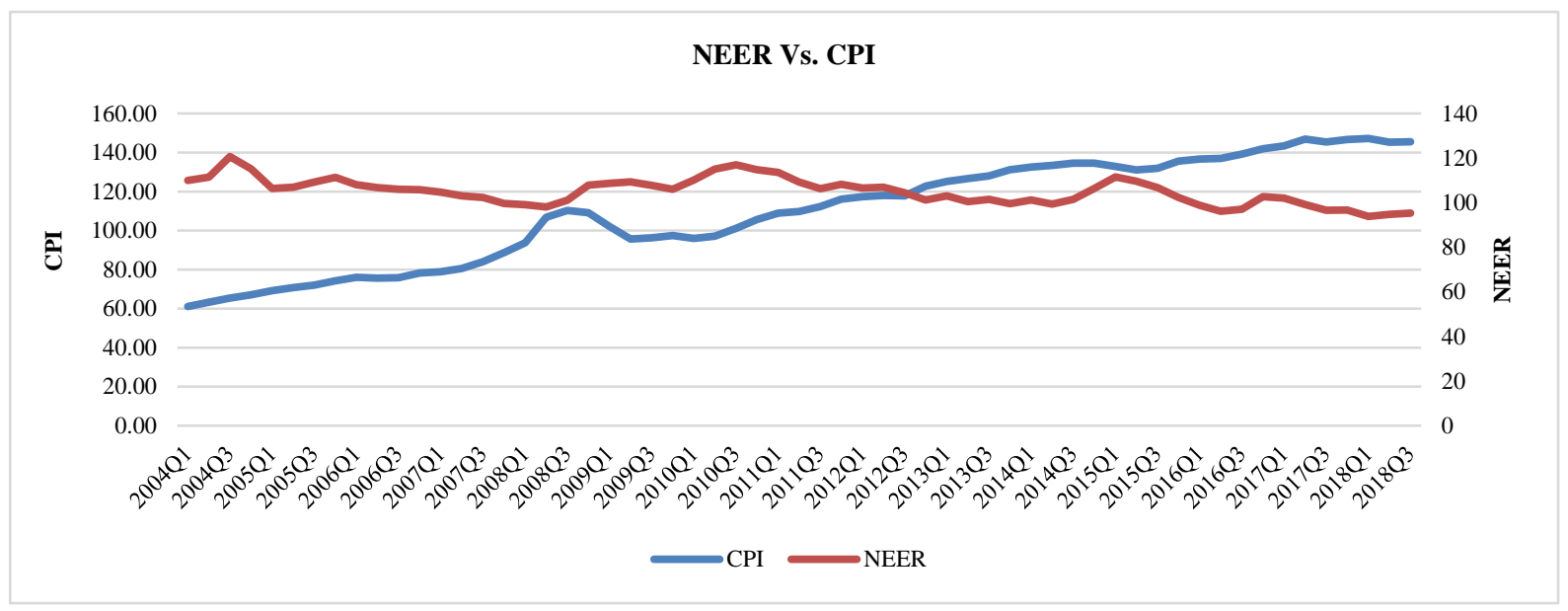

Figure 1. Nominal Effective Exchange Rate and CPI movements

Source: Author Calculations based on IFS and Bruegel Centre data

(Figure 2) shows two episodes of Afghani, the first is before 2013, and the second one after 2013. The first episode indicates the deterioration and improvement of Afghani against other significant currencies, but the second episode is an inverted scenario. The closing of both curves in 2008 was caused by drought, and the intersection of NEER and CPI dependence on the political environment.

Apart, the dominance of the dollar as a vehicle currency is most frequently used the trading currency. Hence the fluctuation of the exchange rate is translated to the price of imported goods and consumer price, (Figure 2) shows (62.15) percent depreciation in the exchange rate. 


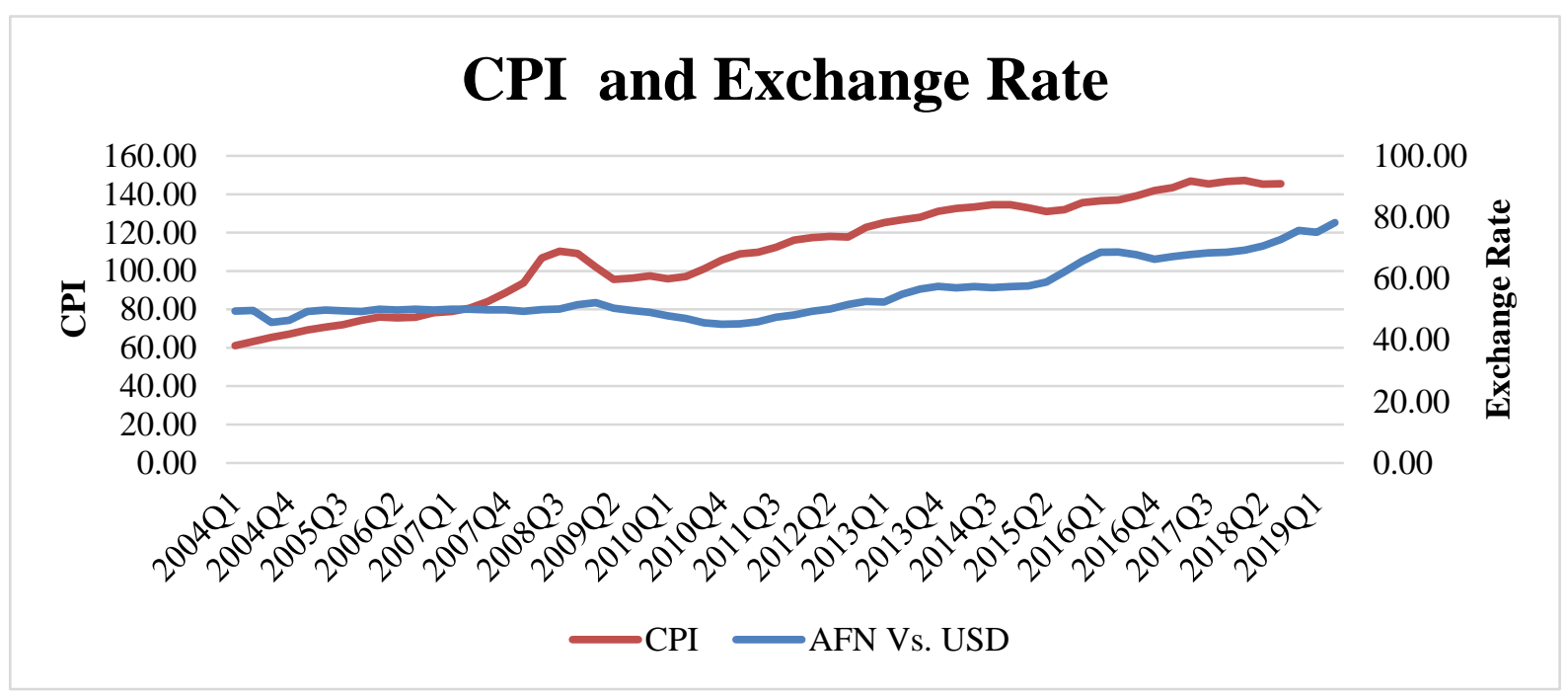

Figure 2. Afghani to USD Exchange Rate and CPI Movements

Source: Author calculations based on IFS data

$\mathrm{DAB}$, in all this time, controlled the inflation rate through the exchange rate managing. DAB used foreign currency auction through the open market operation, as a placebo.

\section{Methodology}

In an effort of empirical modeling of the primary determinant of ERPT in Afghanistan. We examine some uncommon but empirically plausible factors of ERPT for developing countries. We set up a 5-variables VAR model following for ERPT testing in developed countries using the VAR method, (Mccarthy, 2000) McCharty (2000), (Zorzi, Hahn, \& Sánchez, 2003), (Faruqee, 2004 )Faruqee (2004) and (Ito \& Sato, 2006) that uses VAR/VECM in viewing ERPT at domestic prices in Asia countries in line with (Mansaray, 2011), (Sanusi, 2010), (Lariau et al., 2016).

\subsection{Model and Data}

\subsubsection{Model}

To scrutinize the transmission of exchange rate variation to import and domestic prices Vector Error Correction Model (VECM) is employed to grasp long term and short-term relationships. The sign of coefficient in VECM plays a deterministic role in studying how ERPT transmitted to domestic price.

Vector Error Correction Model (VECM) is a form of Vector Autoregressive (VAR) which is characterized by none stationarity at level (none stationary at I (0), but stationary at first difference (stationary at I (1) accompanied by co-integration (Mills, 2019).

$$
\boldsymbol{Y}_{t}=\beta_{0}+\beta_{1} X_{t}+\varepsilon_{t}
$$

The relationship between Error Correction Model (ECM) and co-integration equation $Y_{t}$ and $X_{t}$ are as follows:

$$
\varepsilon_{t-1}=Y_{t-1}-\beta_{0}-\beta X_{t-1}
$$

The Error Correction Models for $Y_{t}$, is as follows

$$
\Delta Y_{\mathrm{t}}=\mu_{\mathrm{Y}}+\alpha_{\mathrm{Y}} \varepsilon_{\mathrm{t}-1}+\sum_{\mathrm{i}=1}^{\mathrm{n}} \alpha_{1 i} \Delta Y_{\mathrm{t}-\mathrm{i}}+\sum_{\mathrm{i}=1}^{\mathrm{n}} \mathrm{b}_{1 \mathrm{i}} \Delta X_{\mathrm{t}-\mathrm{i}}+\mu_{\mathrm{Yt}}
$$

The Exchange rate is taken as one of the endogenous variable that react to economic policies because, in the floating exchange rate system, the exchange rate is not an influential factor of prices likewise it is effected by other factors such as inflation, money supply, demand shock, the price of the imported good and so on.

The deterministic relationship between domestic prices and the exchange rate builds a reinforcing mechanism between both of them. This mechanism is possible to be explored through Cholesky Decomposition of Innovations to identify structural shocks, studying of ERTP into a set of domestic prices along the pricing chain from the importer/producer stage to the consumer level. All variables of the dataset are in the natural log-transformed form (Ito \& Sato, 2006). 


\subsubsection{Data}

To study the transmission mechanism of the pass-through effect of exchange rate variations to domestic price and dynamism among economic activities, policy implication, and the price in Afghanistan, the period covered by quarterly data between (2003q1 and 2019q2). The dataset of research is designed according to the DAB policy measures and the availability of data.

Unavailability high-frequency data constrained the chance of methods selection for empirical study.

Hence we have selected 5- variables (CPI, WFPI, FR, MS, NEER, and IMP) (Note 1). The data of foreign reserves are compiled from (DAB annual bulletins and IFS databank); CPI, MS, and Imports are from IFS and NEER from Bruegel Centre database obtained.

World Food Price Index (WFPI) is used as a proxy to capture supply shock because of its significant contribution to the balance of trade as imported goods. A Foreign Reserve (FR) is used as a control variable, to capture the impact of aid and other capital inflows (Note 2).

To examine monetary policy shock in Afghanistan, Money Supply (M2) is chosen as a proxy, since interest rates are not effective instrument in the context of the Afghan economy, DAB tends to make use of the broad money (M2) as a key intermediate target in support of monetary policy implementation. Broad money is used as a contemporaneously influential variable and the anchor of DAB's monetary policy.

The Nominal Effective Exchange Rate (NEER) is used as a measure of the exchange rate, where an increase in NEER indicates an appreciation of the local currency against the weighted basket of currencies of its trading partners.

The price of imported goods (MP) plays a significant role in the market price determination because of the terrific dependency on imported goods.

\subsection{Order of Integration}

Following the standard approach in time-series analysis, the order of integration of foreign reserves as one of the endogenous variables in the ordering of variables in the equation employed first since it is not expected to be affected concurrently by any other shock due to the reliant on foreign aids and imports of goods from foreign markets. However, foreign reserves are likely to affect all other variables in the system concurrently. A rise in foreign reserves may result in a strong point for national currency and can affect the exchange rate.

The Money Supply (MS) taken as the next variable after (FR), but before the exchange rate because of the monetary policy reaction function in response to international food price variation as well as to demand shock. The Nominal effective exchange rate (NEER) is simultaneously elastic against changes in supply, demand, and shocks of monetary policy exempt price shock. It may be supposed that the exchange rate movements have contemporaneously effect on domestic prices. Subsequently, price is affected by all other factors, so it employed last in the equation. As whole variables are arranged in the following order.

$$
\left\{\Delta W F P_{t}, \Delta \ln F R_{\mathbf{t}}, \Delta \ln M S_{\mathbf{t}}, \Delta \ln N E E R_{\mathbf{t}}, \Delta \ln M P_{\mathbf{t}}, \Delta \operatorname{lnCPI} \mathrm{t}_{\mathbf{t}}\right\}
$$

To assess the impacts of exchange rate changes and other types of shocks on domestic price. We identified the structural shock under the five variable, a Choleski decomposition of is used matrix, to specify the relationship between variance and covariance matrix of reduced form VAR residuals $\left(\mu_{\mathrm{t}}\right)$, to calculate structural disturbance $\left(\varepsilon_{\mathrm{t}}\right)$ the model can be:

$$
\left[\begin{array}{c}
\mu_{\mathrm{t}}^{\mathrm{wfp}} \\
\mu_{\mathrm{t}}^{\mathrm{fr}} \\
\mu_{\mathrm{t}}^{\mathrm{ms}} \\
\mu_{\mathrm{t}}^{\text {neer }} \\
\mu_{\mathrm{t}}^{\mathrm{MP}}
\end{array}\right]=\left[\begin{array}{ccccc}
\mathrm{S}_{11} & 0 & 0 & 0 & 0 \\
\mathrm{~S}_{21} & \mathrm{~S}_{22} & 0 & 0 & 0 \\
\mathrm{~S}_{31} & \mathrm{~S}_{32} & \mathrm{~S}_{33} & 0 & 0 \\
\mathrm{~S}_{41} & \mathrm{~S}_{42} & \mathrm{~S}_{43} & \mathrm{~S}_{44} & 0 \\
\mathrm{~S}_{51} & \mathrm{~S}_{52} & \mathrm{~S}_{53} & \mathrm{~S}_{54} & \mathrm{~S}_{55}
\end{array}\right]\left[\begin{array}{c}
\varepsilon_{\mathrm{t}}^{\mathrm{wfp}} \\
\varepsilon_{\mathrm{t}}^{\mathrm{fr}} \\
\varepsilon_{\mathrm{t}}^{\mathrm{ms}} \\
\varepsilon_{t}^{\text {neer }} \\
\varepsilon_{\mathrm{t}}^{\mathrm{MP}}
\end{array}\right]
$$

\section{Empirical Results and Analysis}

\subsection{Stationary Test}

To plug in the data into the model stationarity test is the essential requirement. As a whole, the computed result shows, all data are stationary at I (1). For stability of the model, see appendix (A). 
Table 1. Stationarity Test (Probabilities in brackets)

\begin{tabular}{ccccc}
\hline \multirow{2}{*}{ Variable } & \multicolumn{2}{c}{ Level } & \multicolumn{2}{c}{ First Difference } \\
\cline { 2 - 5 } & Intercept & Trend \& Intercept & Intercept & Trend \& Intercept \\
\hline wfp & $-2.204956(0.2067)$ & $-1.428075(0.8425)$ & $-6.006248(0.0000)$ & $-6.336045(0.0000)$ \\
fr & $-4.419161(0.0007)$ & $-1.209816(0.8991)$ & $-2.031658(0.2728)$ & $-8.006643(0.0000)$ \\
ms & $-2.296388(0.1764)$ & $0.016981(0.9957)$ & $-3.242037(0.0222)$ & $4.108527(0.0102)$ \\
neer & $-1.946290(0.3094)$ & $-3.080257(0.1204)$ & $-5.481867(0.0000)$ & $5.460025(0.0002)$ \\
import & $-2.222459(0.2013)$ & $-0.317769(0.9878)$ & $-5.529497(0.0000$ & $-6.171578(0.0000)$ \\
\hline
\end{tabular}

Source: Author's calculation with E-views 10

\subsection{Co-integration Test}

The next step is the co-integration test. Hence we conduct Johanson's co-integration test for log (WFPI, FR, MS, NEER, IMP, and CPI) the software reports two different types of test statistics: Trace statistics and maximum eigenvalue statistics. Both methods, in general, show similar decisions on the number of co-integration relations.

The lag length selection criteria, with a maximum lag length of 8, suggest a lag length of two as appropriate lag for the VAR model. Akaike Information Criteria (-19.52200), Schwartz Bayesian Criteria (-16.35912), Hannan-Quinn (-18.34905) and Final Prediction Error (1.49e-16).

The output of the unrestricted co-integration rank test shows a positive single co-integration relation to rejecting the null hypothesis at 5 percent significance, we conclude with the long-run relationship among the variables.

Moreover, Johanson's co-integration test estimates the long-run and short-run relationship of the variables incorporated in the model.

Table 2. Co-integration Test

\begin{tabular}{|c|c|c|c|c|c|c|c|c|c|}
\hline \multicolumn{5}{|c|}{ Unrestricted Co-integration rank test (Trace) } & \multicolumn{5}{|c|}{ Unrestricted Co-integration rank test (Maximum eigenvalue) } \\
\hline $\begin{array}{l}\text { Hypothesized } \\
\text { No. of CE(s) }\end{array}$ & Eigenvalue & $\begin{array}{l}\text { Trace } \\
\text { Statistics }\end{array}$ & $\begin{array}{l}0.05 \text { Critical } \\
\text { Value }\end{array}$ & Prob. & $\begin{array}{l}\text { Hypothesized } \\
\text { No. of CE(s) }\end{array}$ & Eigenvalue & $\begin{array}{l}\text { Max-Eigen } \\
\text { Statistics }\end{array}$ & $\begin{array}{l}0.05 \text { Critical } \\
\text { Value }\end{array}$ & Prob. \\
\hline None* & 0.638351 & 111.2150 & 95.75366 & 0.0028 & None* & 0.638351 & 45.76866 & 40.07757 & 0.0103 \\
\hline At most 1 & 0.439150 & 65.44634 & 69.81889 & 0.1062 & At most 1 & 0.439150 & 26.02355 & 33.87687 & 0.3193 \\
\hline At most 2 & 0.372532 & 39.42280 & 47.85613 & 0.2438 & At most 2 & 0.372532 & 20.97284 & 27.58434 & 0.2779 \\
\hline At most 3 & 0.237634 & 18.44996 & 29.79707 & 0.5330 & At most 3 & 0.237634 & 12.20976 & 21.13162 & 0.5271 \\
\hline At most 4 & 0.125555 & 6.240193 & 15.49471 & 0.6671 & At most 4 & 0.125555 & 6.037471 & 14.26460 & 0.6084 \\
\hline At most 5 & 0.004495 & 0.202723 & 3.841466 & 0.6525 & At most 5 & 0.004495 & 0.202723 & 3.841466 & 0.6525 \\
\hline
\end{tabular}

Source: Author's calculation with E-views 10

\subsection{Error Correction Models (ECMs)}

According to the result of the Johansen test, the existence of the co-integration relationship. Now we can estimate an error correction model (ECM). The long-run relationship estimates with VECM approach with the co-integration equation.

\subsubsection{Co-integration Equation}

$$
E C T_{t-1}=\operatorname{lncpi}_{t-1}-\beta_{0}-\beta_{1} \ln w f p_{t-1}-\beta_{2} \operatorname{lnfr} r_{t-1}-\beta_{3} m s_{t-1}-\beta_{4} \operatorname{lneer} r_{t-1}-\beta_{5} \ln M P_{t-1}
$$

\subsubsection{ECM for CPI}

$$
\begin{aligned}
& \Delta \operatorname{lncpi}_{t}= \\
& \pi_{\text {lncpi }}+\alpha_{\text {lncpi }} \varepsilon_{t-1}+\sum_{i=1}^{2} \alpha_{i} \Delta \operatorname{lncpi}_{t-1}+\sum_{i=1}^{2} \omega_{i} f r_{t-1}+\sum_{i=1}^{2} \zeta_{i} \Delta \operatorname{lnms}_{t-1}+\sum_{i=1}^{2} \theta_{i} \Delta \text { lnneer }_{t-1}+ \\
& \sum_{i=1}^{2} \varphi_{i} \Delta \operatorname{lnMPP_{t-1}}+\mu_{\text {lncpi } t}
\end{aligned}
$$

Table 3. Co-integration and EC estimates

\begin{tabular}{llll}
\hline Coefficient & Estimates & t-stats \\
\hline Long-run Co-integration estimation & & & \\
\hline$Y_{t-1}$ & 1.000000 & & - \\
$\beta_{0}$ & & -14.53306 & - \\
$\beta_{1}$ & & -0.284698 & -1.33930 \\
\hline
\end{tabular}




\begin{tabular}{lll}
\hline$\beta_{2}$ & 4.482026 & 6.32816 \\
$\beta_{3}$ & -2.483345 & -4.24606 \\
$\beta_{4}$ & 3.259571 & 4.18747 \\
$\beta_{5}$ & -1.656674 & -4.92645 \\
\hline Short-run ECM estimation & & \\
\hline Speed of Adjustment Coefficient & -0.034224 & -1.42356 \\
$\Delta$ lncpi & 0.372133 & 2.07097 \\
& -0.170761 & -1.08427 \\
$\Delta$ lnwfp & 0.146365 & 2.55566 \\
& 0.042398 & 0.65876 \\
$\Delta$ lnfr & 0.088590 & 0.92649 \\
& 0.104657 & 1.31693 \\
$\Delta$ lnms & -0.124943 & -1.30602 \\
$\Delta$ lnneer & -0.133286 & -1.53633 \\
$\Delta$ lnimport & 0.036008 & 0.25046 \\
& -0.002327 & -0.01349 \\
\hline
\end{tabular}

Source: Author's calculation with E-views 10

By the plugin, the estimated values of $\beta(\mathbf{s})$ in the equation (5) we will have the long-run relationship as below.

$$
E C T_{t-1}=1.000 \operatorname{lnCPI}_{t}-0.285 \operatorname{lnWPFI}_{t}+4.482 \ln F R C_{t}-2.484 \ln M S_{t}+3.2301 \ln N E E R_{t}-1.657 \ln \operatorname{lMP}_{t}-14.533
$$

And in the short-run, the departure from long-run equilibrium correct each period with the speed of adjustment of $(-0.034224)$ it means that the equilibrium in each quarter resumes with $(3.42 \%)$ (Enders, 2015).

$$
\begin{array}{r}
\Delta \operatorname{lncpi}_{t}=-0.035 \operatorname{ETC}_{t-1}+0.372 \Delta \ln C P I_{t-1}-0.1708 \Delta \ln C P I_{t-2}+0.146 \Delta \ln W P F I_{t-1}+ \\
0.0424 \Delta \ln W P F I_{t-2}+0.089 \Delta \ln F R C_{t-1}+0.105 \Delta \ln F R C_{t-2}-0.125 \Delta \ln M S_{t-1}-0.133 \Delta \ln M S_{t-2}+ \\
0.036 \Delta \ln N E E R_{t-1}-0.002 \Delta \ln N E E R_{t-2}-0.018 \Delta \ln I M P_{t-1}-0.033 \Delta \ln I M P_{t-2}
\end{array}
$$

\section{Dynamic Behaviour of the Variables}

The dynamic pass-through elasticity of variables to prices is assessed by adopting the impulse response functions (IRFs). For every variable, the shock of each variable is defined by a separate equation. The impulse response function affects the VAR system over time. Here, the response of variable to one standard deviation shock to other variables through the dynamic structure of VAR using Cholesky decomposition.

The IRFs obtained from the estimated VARs are plotted in (Figure 6) for ten quarters' time horizon, which the responses are statistically significant. The IRF of import price is swift, which initially negative, but later it is positive and moves into the positive horizon after the third quarter, which is highly responsive against the shock; import price has a smooth increasing movement after the ninth quarter. It implies that import prices respond to the exchange rate shock from the third period onwards in Afghanistan. Since any increase in the exchange rate presents the depreciation of the Afghanis against the corresponding currencies. Accordingly, under the light of this definition, the depreciation of the exchange rate increases imports prices.

The IFR of inflation has an increasing trend against one standard deviation shock in the exchange rate in the short-run (to the fifth quarter), but with the beginning of the sixth quarter, the trend smoothly declines, which is the result of managed exchange rate policy. However, in the long-run, evident by positive and responsive inflation, it suggests that domestic prices respond to the shocks in the exchange rate from the ninth quarter onward highly responsive.

Accordance to the structure of the import side of the trade balance and its content in the import prices in the import price index, it is firm to be highly responsive to the exchange rate changes than other variables. 
Response to Cholesky One S.D. Innovations \pm 2 S.E.

Response of LCPI to LNEER

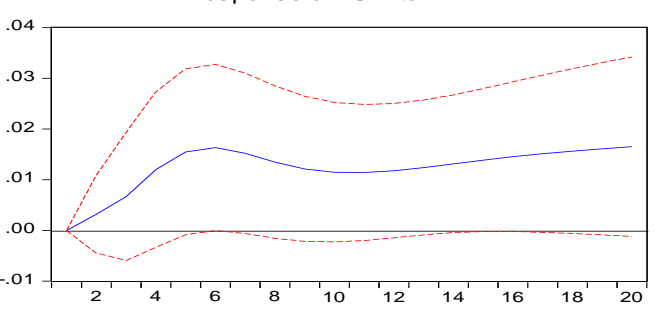

Response of LFRC to LNEER

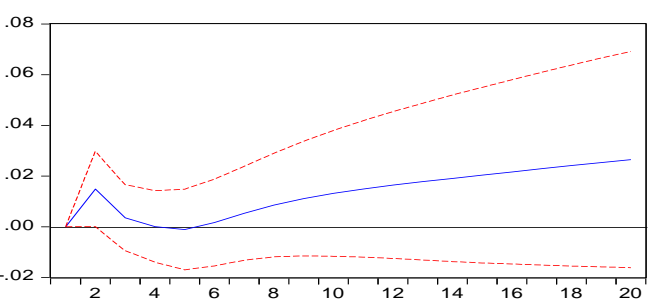

Response of LIMPORT to LNEER

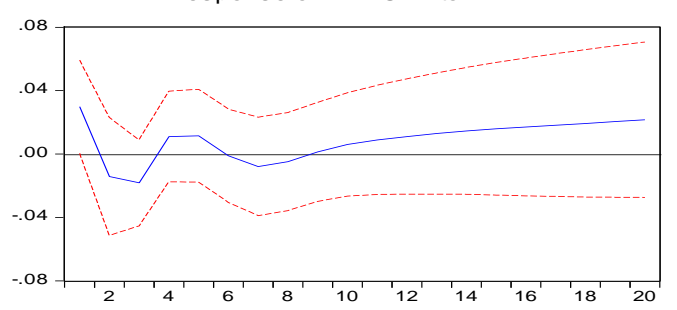

Figure 3. Impulse Responses of CPI, WFP, FRC, LMS, Import price to NEER
Response of LWFP to LNEER
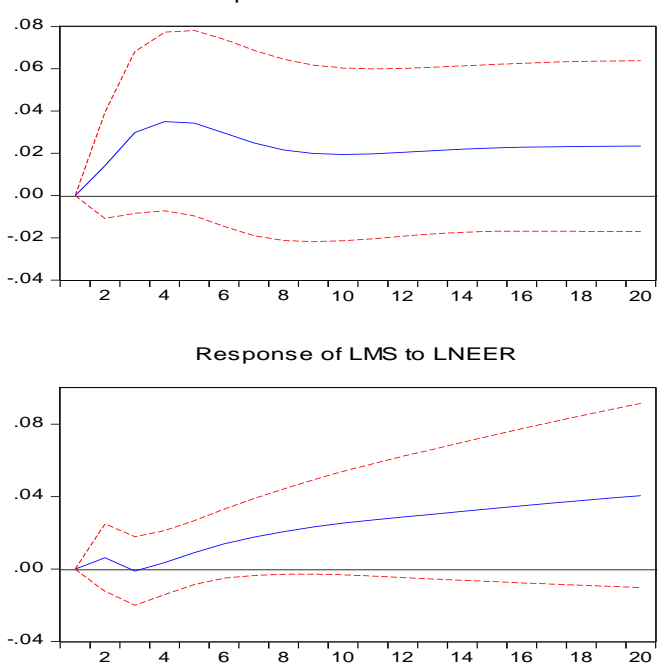

Source: Author's calculation with E-views 10

\section{Variance Decomposition}

The (Figure 7) indicates the results of FEVDs over a forecast horizon of 10-quarters. It found that the composite shocks of their own explain the majority of the error variance of the variable.

The variance of import price is respectively explained by FR, NEER, CPI, and MS in the short-run and long-run significantly. Likewise, the variation in NEER is followed by approximately $(8.2 \%)$ CPI in the short-run with downing trends in the long-run, and (16\%) for FR. On the other hand, the variation of CPI is approximately strongly lagged by its variance; at quarter five, about $(1 \%)$ is for NEER, and import price is, on the other hand, CPI variation is firmly explained by WFP in the long-run.

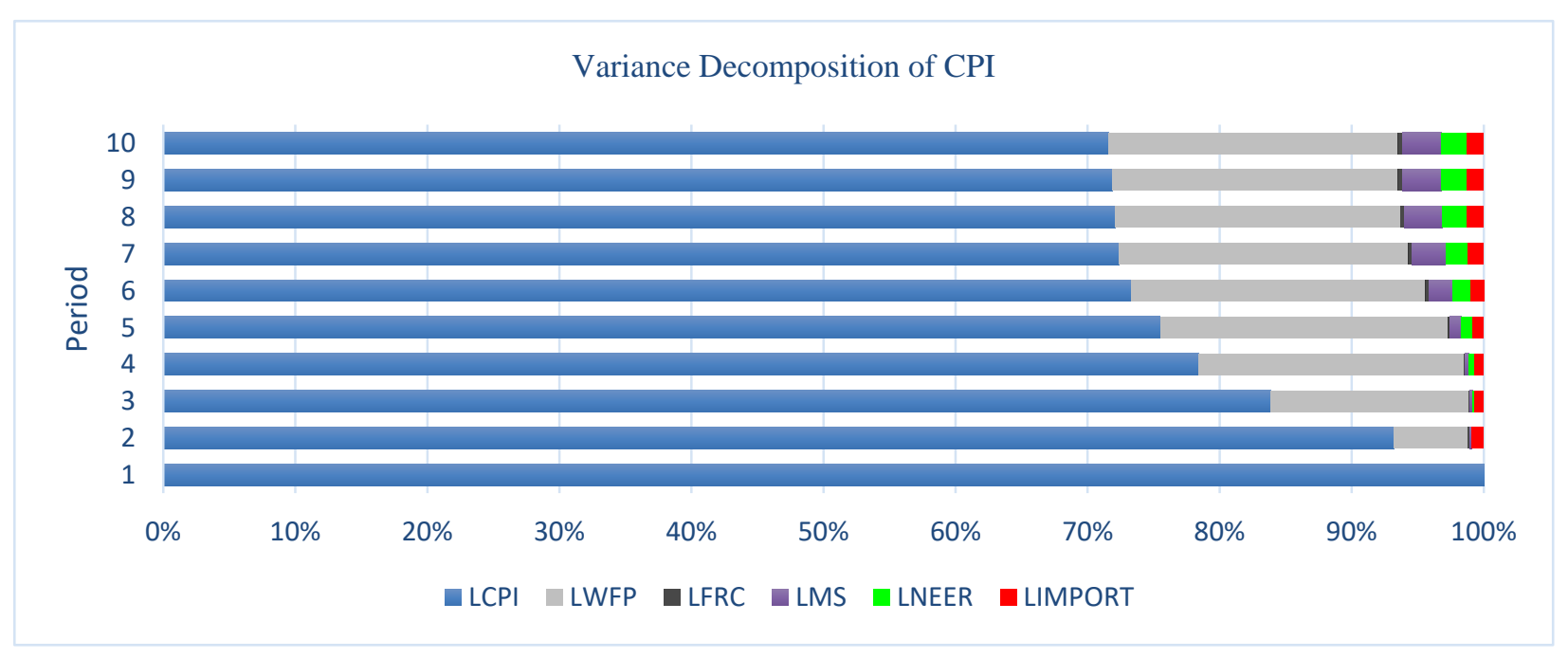


Variance Decomposition of Improt price

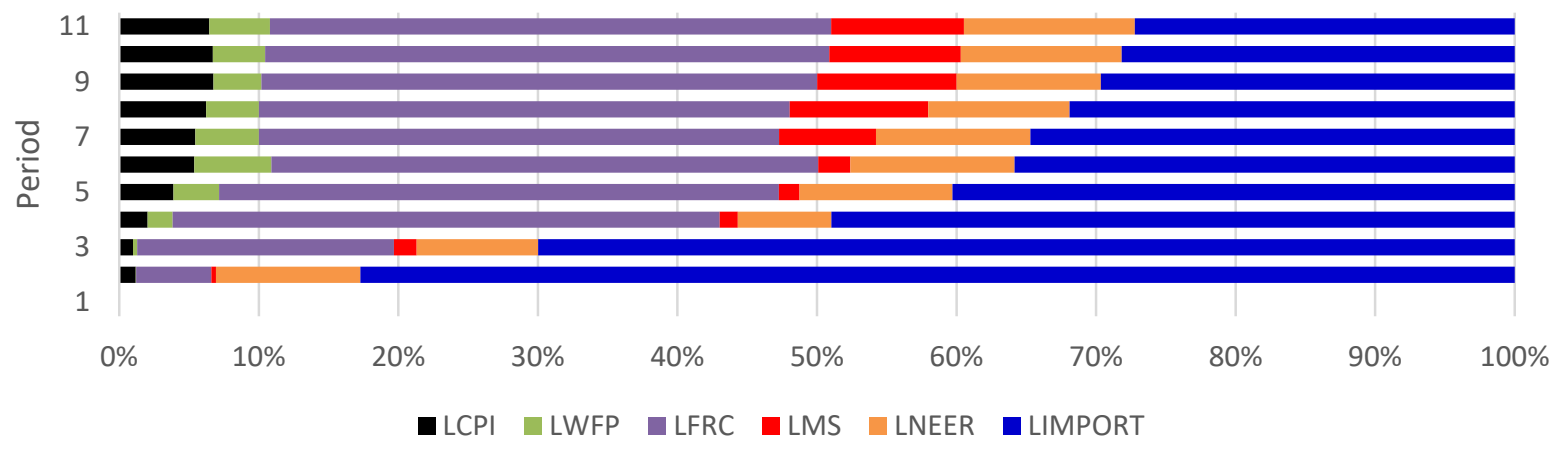

Variance Decomposition of Ms

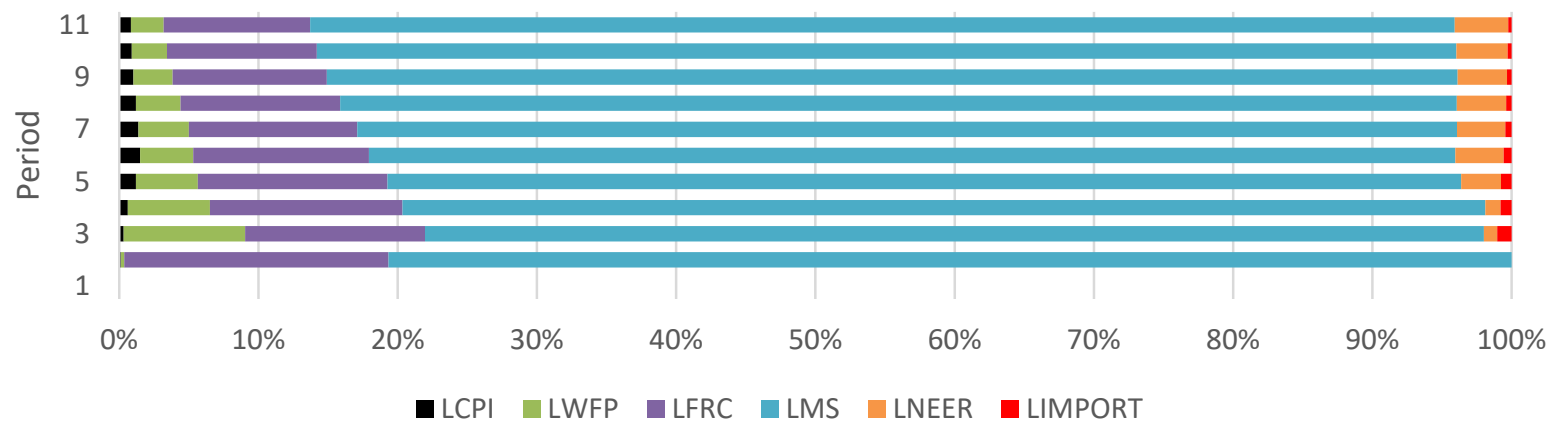

Variance Decomposition of NEER

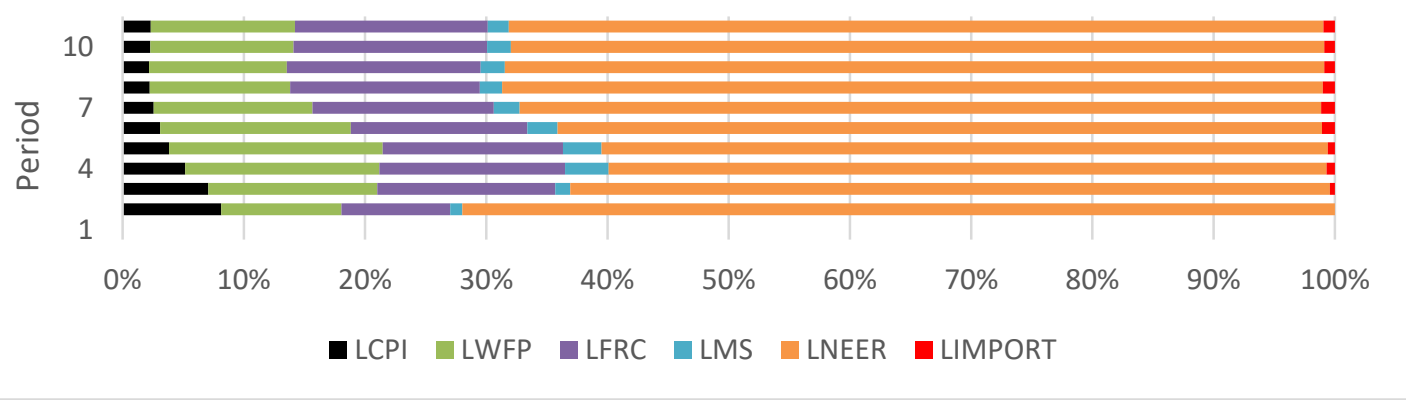

Variance Decomposition of FR

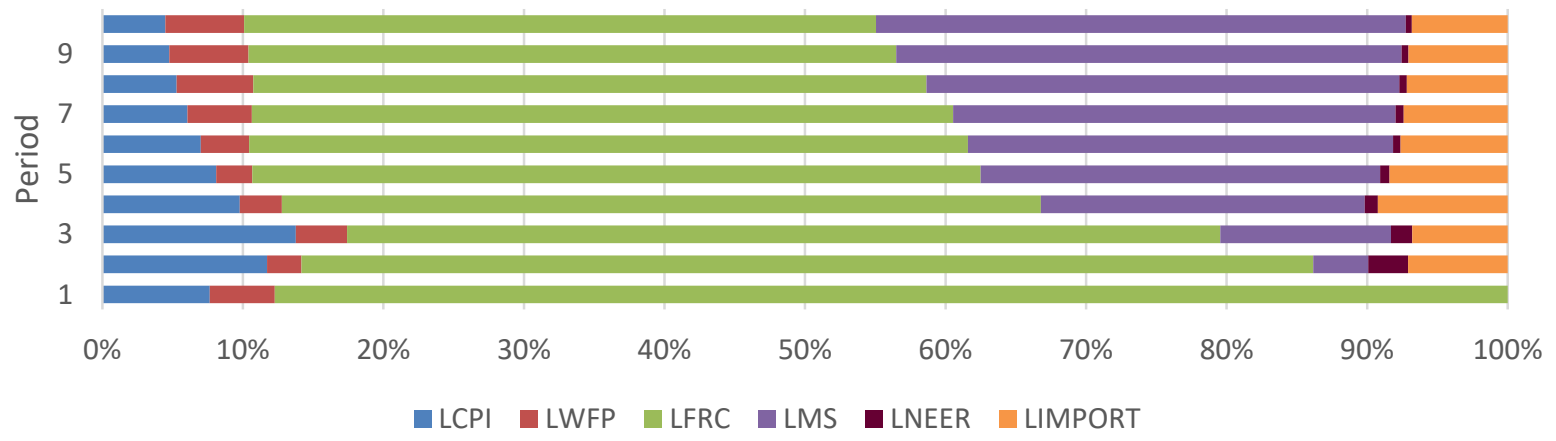

Figure 4. Forecast Error Variance Decomposition of Interest Variables

Source: Author's calculation with E-views 10 and Excel 


\section{Conclusion and Recommendations}

The degree of exchange rate pass-through has essential implications for the formulation of monetary policy to contract inflation as well as trade implication of an exchange rate shock. This study empirically investigated the exchange rate pass-through effects, dynamic and quantity based on VECM and impulse-response. In line with other most empirical studies, the result of this study indicates that the exchange rate pass-through is incomplete. Import prices respond swiftly to the exchange rate movements initially vibrate about $(-2,+2)$ percent, but after the $9^{\text {th }}$ quarter, follow-up a smooth upward trend. However, CPI responds to the exchange rate fluctuation is positive approximately $(+2)$ percent in the period $5^{\text {th }}$; likewise, CPI elasticity curve departs with little changes around $(+2)$ percent up to the period $20^{\text {th }}$.

The analysis of variance decomposition presents that foreign reserves (FR) are strongly explained by MS, Import and CPI; meanwhile, the import is firmly affected by foreign reserves currency, NEER, MS, and CPI.

Consequently, we can conclude that prices, both import prices, and domestic prices, are swiftly elastic to the changes in the exchange rate. In the short-run, the little distortion of the price is possible by policy intervention in the market, especially the auction of foreign currency with two frequencies in a week, and some time due to the administrative price-setting scheme. However, in the long run, the pass-through effect is relatively high, given the country heavily reliant on import and less diversified economic structure.

Based on these findings the following policies could be considered for Afghanistan

Taking some pivotal course of action to accelerate the structural reforms in pursuit of economic diversification. The relatively low pass-through effect is bearing by foreign reserves through foreign aids. Alongside this reduction of dependency on imports, especially consumable goods should be considered.

Substitute currencies constraint the flexible implication of monetary policies, which decline the effectiveness of the monetary strategy, therefore, to restore full policy flexibility; Da Afghanistan Bank, and policymaker as a whole should undertake an active policy to displacing substitute currencies with Afghani as a national currency.

It should be essential for DAB to switch policy form heavy on posture to heavy on strategy. The policy of light on strategy results in placebo effects. A simple trend analysis of macroeconomics variables shows economic slowdown because of the reduction of foreign aids - otherwise, the running on the current path triggering the demolishing of the value of the national currency.

The reduction in foreign aids triggering the demolition of national currency if the policy running on the current path with current disposal (placebo) policy effect.

The monetary authorities should consistent, credible, and sustainable policies. They should activate all the complementary policy instruments to define the policy framework that supports the flexible exchange rate regime and monetary policy anchors.

\section{References}

An, L. (2006). Exchange Rate Pass-Through: Evidence Based on Vector Autoregression with Sign Restrictions. Department of Economics, University of Kentucky, Lexington, KY, 40506.

Auer, R. A. (2015). Exchange Rate Pass-Through, Domestic Competition, and Inflation: Evidence from the 2005 - 08 Revaluation of the Renminbi. Journal of Money, Credit and Banking (Vol. 47). CESifo Working Paper No. 3759.

Berman, N., Martin, P., \& Mayer, T. (2014). How do different exporters react to exchange rate changes? Theory, empirics and aggregate implications. Discussion Paper Series (No. 7493) Centre for Economic Policy Research. Retrieved from https://hal-sciencespo.archives-ouvertes.fr/hal-00973027.

Bhattacharya, R., Patnaik, I., \& Shah, A. (2011). Monetary Policy Transmission in an Emerging Market Setting. IMF Working Papers, 11(5), 1. https://doi.org/10.5089/9781455211838.001

Bogdanski, J., Tombini, A. A., \& Werlang, S. R. C. (2000). Implementing Inflation Targeting in Brazil. Banco Central do Brasil, Working Paper Series.

Burstein, A., Eichenbaum, M., \& Rebelo, S. (2002). Why Are Rates of Inflation so Low After Large Develuation? NBER Working Paper No. 8748. https://doi.org/ 10.3386/w8748.

Campa and Goldberg. (2002). Pass-Through of Exchange Rates to Consumption Prices What Has Changed and Why? (Vol. 17). Review of Economics and Statistics. https://doi.org/ 10.1162/003465305775098189

Campa, J. M., \& Goldberg, L. S. (2005). Exchange Rate Pass-Through to Import Price in the Euro Area. NBER 
Working Paper No. 8934. https://doi.org/ 10.3386/w8934

Carrière-Swallow et al. (2016). Monetary Policy Credibility and Exchange Rate Pass-Through. IMF Working Papers (No. WP/16/240). https://doi.org/ 10.5089/9781475560312.001

Choudhri, E. U., \& Hakura, D. S. (2006). Exchange rate pass-through to domestic prices: Does the inflationary environment matter? Journal of International Money and Finance. https://doi.org/10.1016/j.jimonfin.2005.11.009

Decree, No. 808. (2003). Official Gazette, Islamic State of Afghanistan, Ministry of Justice.

Devereux, M. B., \& Engel, C. (2002). Exchange rate pass-through, exchange rate volatility, and exchange rate disconnect. NBER Working Paper No. 8858. https://doi.org/10.3386/w8858

Dornbusch, R. (1985). Exchange Rate and Prices. NBER Working Paper No. 1769. Retrieved from https://www.nber.org/papers/1769.

Enders, W. (2015). Applied econometric time series (4th ed). Hoboken, NJ: Wiley.

Engel, C. (2000). Optimal Exchange Rate Policy: The Influence of Price Setting and Asset Markets. NBER Working Paper No. 7889. Retrieved from https://www.nber.org/papers/w7889

Faruqee, H. (2006). Exchange Rate Pass-Through in the Euro Area. International Monetary Fund. IMF Staff Papers Vol. 53, No. 1.

Frankel, J., Parsley, D., \& Wei, S. (2005). Slow Passthrough Around the World: A New Import for Developing Countries? NBER Working Paper 11199. https://doi.org/10.3386/w11199

Gagnon, J. E., \& Ihrig, J. (2001). Monetary Policy and Exchange Rate Pass Through. https://doi.org/10.1002/ijfe.253

Gaulier, Guillaume. Lahrèche-Révil \& Méjean. (2006). Structural Determinants of the Exchange-Rate Pass-Through.CEPII Working Paper 2006- 0, CEPII.

Georgios, G., Gr”ab, J., \& Khalil, M. (2017). Global Value Chain Participation and Exchange Rate. The European Central Bank (ECB) Working Paper Series No 2327.

Goldberg, P. K., \& Kenetter, M. M. (1997). Goods Prices and Exchange Rates: What Have We Learned? Journal of Economic Literature, 35(3), 1243-1272. Retrieved from http://www.jstor.org/stable/2729977

Helmy, O., Fayed, M., \& Hussien, K. (2018). Exchange rate pass-through to inflation in Egypt: A structural VAR approach. Review of Economics and Political Science, 3(2), 2-19. https://doi.org/10.1108/REPS-07-2018-001

Ito, T., \& Sato, K. (2006). Exchange Rate Changes and Inflation in Post-Crisis Asian Economies: VAR Analysis of the Exchange Rate Pass-Through. NBER Working Paper No. w12395. https://doi.org/10.3386/w12395

Khundrakpam, J. K. (2007). Economic reforms and exchange rate pass-through to domestic prices in India. SSRN Electronic Journal. https://doi.org/10.2139/ssrn.1012584

Knetter, M. M. (1993). International Comparisons of Pricing-to-Market Behavior. American Economic Association, 83(3), 473-486. http://www.jstor.org/stable/2117529

Krugman, P. (1986). Pricing to Market when the Exchange Rate Changes. NBER Working Paper No. w1926. https://doi.org/10.3386/w1926

Krugman, P. R., \& Obstfeld, M. (2003). International economics: Theory and policy (6th ed.). Boston: Addison Wesley.

Laflèche, T. (1996). The impact of exchange rate movements on consumer prices. Research Department, Bank of Canada Review.

Lariau, A., El-Said, M., \& Takebe, M. (2016). An Assessment of the Exchange Rate Pass-Through in Angola and Nigeria. IMF Working Papers, 16(191), 1. https://doi.org/10.5089/9781475537529.001

Mansaray, K. (2011). Estimating the Monetary Policy Reaction Function for Sierra Leone: An Econometric Approach. Journal of Monetary and Economic Integration, 11(2).

Mccarthy, J. (2000). Pass-Through of Exchange Rates and Import Prices to Domestic Inlfation in Some Industrialized Economies. In Federal Reserve Bank of New York.

Menon, J. (1995). Exchange rate pass-through. Journal of Economic Surveys. 
https://doi.org/10.1111/j.1467-6419.1995.tb00114.x

Mills, T. C. (2019). Applied time series analysis (1st ed). Cambridge, MA: Elsevier.

Ozkan, I., \& Erden, L. (2015). Time-varying nature and macroeconomic determinants of exchange rate pass-through. International Review of Economics and Finance. https://doi.org/10.1016/j.iref.2015.01.007

Reinhart, C. M., Rogof, K. S., \& Savastano, M. A. (2014). Addicted to Dollars. NBER Working Paper No. 10015. https://doi.org/ 10.3386/w10015

Rowland, P. (2003). Exchange Rate Pass-Through to Domestic Prices: The Case of Colombia. https://doi.org/10.32468/espe.4703

Sanusi, A. R. (2010). Exchange Rate Pass-Through to Consumer Prices in Ghana: Evidence from Structural Vector Auto-Regression. 24.

Schmidt-Hebbel, K., \& Tapia, M. (2002). Inflation targeting in Chile. North American Journal of Economics and Finance, 13, 125-146. https://doi.org/10.1016/S1062-9408(02)00076-1

Smets and Wouters. (2002). Openness, Imperfect Exchange Rate Pass-Through and Monetary Policy. European Central Bank. working paper NO. 128

Taylor, J. B. (2000). Low Inflation, Pass -Through, and the Pricing Power of Firms. European Economic Review, 44(7). https://doi.org/ 10.1016/S0014-2921(00)00037-4

Terra, C. (2015). Principles of International Finance and Open Economy Macroeconomics. https://doi.org/10.1016/C2014-0-01416-5

Yang, J. (1997). Exchange rate pass-through in u.s. Manufacturing industries. Review of Economics and Statistics. https://doi.org/ 10.1162/003465397556430

Zorzi, M. C., Hahn, E., \& Sánchez, M. (n. d.). Exchange rate pass-through in emerging markets. Eropean Central Bank working paper No. 739

\section{Notes}

Note 1. Due to the large ratio of import to GDP (M/GDP) other control variables are not taken into account. Meanwhile, Local demand conditions are unobservable. Hence, the cyclical component of output may not be the most appropriate measure of the output gap in foreign aid reliant economy. The best approach would be to quantify potential output, but this is not possible in this case given the limited data availability. Further, as the acute deficit of the balance of trade (90\%) the output gap influential impact is not plausible.

Note 2. Foreign reserves determined out of the economic system particularly, through foreign aid during the interesting period.

\section{Appendix A}

\section{Diagnostic Test of Model}

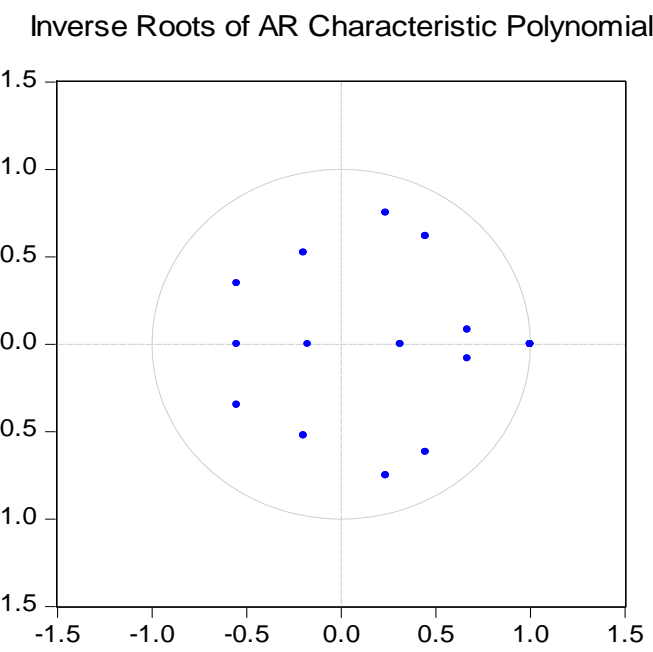

Figure A.1. Test for Stability 
Table A.1. Serial Correlation LM Tests

\begin{tabular}{lrl}
\hline \multicolumn{2}{l}{ VEC Residual Serial Correlation LM Tests } & \\
\hline \multicolumn{1}{l}{ Lags } & LM-Stat & \\
\hline 1 & 35.60427 & 0.4873 \\
2 & 42.82251 & 0.2017 \\
3 & 34.62854 & 0.5338 \\
4 & 42.60775 & 0.2081 \\
\multicolumn{2}{l}{ Probs from chi-square with 36 df. } \\
\hline
\end{tabular}

Table A.2. VEC Residual Normatlity Tests

\begin{tabular}{cccc}
\hline Component & Jarque-Bera & df & Prob. \\
\hline 1 & 8.728993 & 2 & 0.0127 \\
2 & 0.546389 & 2 & 0.7609 \\
3 & 0.224033 & 2 & 0.8940 \\
4 & 0.417279 & 2 & 0.8117 \\
5 & 1.759450 & 2 & 0.4149 \\
6 & 1.368635 & 2 & 0.5044 \\
Joint & 13.04478 & 12 & 0.3658 \\
\hline
\end{tabular}

Table A.3. VEC Residual Heteroskedasticity Tests

\begin{tabular}{cccc}
\hline & & \\
\hline Joint test: & Prob. \\
\hline 572.2893 & df & 0.2109 \\
\hline
\end{tabular}

\section{Copyrights}

Copyright for this article is retained by the author(s), with first publication rights granted to the journal.

This is an open-access article distributed under the terms and conditions of the Creative Commons Attribution license (http://creativecommons.org/licenses/by/4.0/). 